\section{Sensory Quality of 'Bing' Sweet Cherries Following Preharvest Treatment with Hydrogen Cyanamide, Calcium Ammonium Nitrate, or Gibberellic Acid}

\author{
Murray Clayton and William V. Biasi \\ Department of Plant Sciences, University of California, One Shields Avenue, \\ Davis, CA 95616

\section{Tayfun Agar \\ Department of Horticulture, University of Çukurova, 01330 Adana, Turkey}

Stephen M. Southwick and Elizabeth J. Mitcham ${ }^{1}$

Department of Plant Sciences, University of California, One Shields Avenue, Davis, CA 95616

Additional index words. Prunus avium, $\mathrm{CH}_{2} \mathrm{~N}_{2}, \mathrm{CaNH}_{4} \mathrm{NO}_{3}, \mathrm{GA}_{3}$, firmness, sweetness, tartness, flavor

\begin{abstract}
Bing' sweet cherry (Prunus avium L.) trees were treated with hydrogen cyanamide $\left(\mathrm{CH}_{2} \mathrm{~N}_{2}\right)$ or calcium ammonium nitrate $\left(\mathrm{CaNH}_{4} \mathrm{NO}_{3}\right)$ during dormancy, or gibberellic acid ( $\left.\mathrm{GA}_{3}\right) \mathbf{2 6}$ days before harvest during three consecutive years. Fruit were evaluated at harvest for sensory taste quality using twenty trained panelists sampling for firmness, sweetness, tartness, and cherry flavor. Nondestructive instrumental firmness preceded destructive sensory firmness on the same untreated and $\mathbf{G A}_{3}$-treated cherries in one year when used as a supplementary evaluation. Sensory firmness was consistently higher in $\mathrm{GA}_{3}$ fruit and to a lesser extent in $\mathrm{CH}_{2} \mathrm{~N}_{2}$ fruit than in $\mathrm{CaNH}_{4} \mathrm{NO}_{3}$ and untreated fruit. Instrumental firmness of $\mathrm{GA}_{3}$ fruit did not increase significantly compared with untreated fruit yet instrumental firmness of each treatment correlated relatively well with perceived sensory firmness. Sensory sweetness and cherry flavor scored very similarly, yet both attributes simultaneously varied between treatments across the years. Perceived sensory tartness of treated fruit was variable among years; yet, on average, was rated among treated and untreated fruit as similar. Under the assumption that elevated sensory firmness, sweetness, and cherry flavor intensity reflects improved sweet cherry quality, $\mathbf{G A}_{3}$ fruit were rated of higher quality than untreated fruit given their increased firmness and similar or occasionally elevated sweetness and cherry flavor intensity. $\mathrm{CH}_{2} \mathrm{~N}_{2}$ fruit maintained quality similar to that of untreated fruit, despite often having marginally higher firmness, due to similar or reduced ratings for sweetness and cherry flavor intensity. Notwithstanding similar firmness between $\mathrm{CaNH}_{4} \mathrm{NO}_{3}$ and untreated cherries, sensory quality of $\mathrm{CaNH}_{4} \mathrm{NO}_{3}$-treated cherries was reduced due to their often-diminished levels of perceived sweetness and cherry flavor.
\end{abstract}

Significant quality-related problems in eastern United States retail markets have been documented in sweet cherry fruit supplied from the western U.S. (Ceponis and Butterfield, 1981). In combination with increased cherry production, additional pressure on traditional markets to absorb the supply of fruit has emphasized the need for improved fruit quality. In recent years, producers have increased their utilization of compounds capable of regulating the fruiting and/or growth characteristics of the trees or fruit. Many growers apply gibberellic acid $\left(\mathrm{GA}_{3}\right)$ before harvest with the intention of increasing fruit firmness. Researchers have documented the effects of $\mathrm{GA}_{3}$ on cherry firmness, size, soluble solids content (Clayton

Received for publication 3 Jan. 2006. Accepted for publication 21 Feb. 2006.

${ }^{1}$ Corresponding author; e-mail ejmitcham@ucdavis. edu.

et al., 2003; Facteau, 1982; Facteau et al., 1985; Looney and Lidster, 1980; Proebsting et al., 1973), and titratable acidity (Proebsting et al., 1973). There appears to be little consensus as to the effects of $\mathrm{GA}_{3}$ on size and soluble solids content. More recently cherry producers have utilized hydrogen cyanamide $\left(\mathrm{CH}_{2} \mathrm{~N}_{2}\right)$ in an attempt to control fruit quality and yield problems related to insufficient or marginal chilling during dormancy (Weis et al., 1998, 1999). $\mathrm{CH}_{2} \mathrm{~N}_{2}$ decreases the activity of the enzyme catalase, causing a sequence of reactions eventually coupled to the oxidative pentose phosphate pathway and leading to an increase in the level of reduced nucleotides, essential for enhanced metabolism and subsequently budbreak. Researchers have studied the effects of $\mathrm{CH}_{2} \mathrm{~N}_{2}$ and calcium ammonium nitrate $\left(\mathrm{CaNH}_{4} \mathrm{NO}_{3}\right)^{2}$ applied in combination with surfactants or dormant oils, on breaking dormancy, coordinating budbreak and flower- ing, and advancing maturation in sweet cherry (Weis et al., 1998, 1999), as well as effects on objective fruit quality (Clayton et al., 2003). However, the postharvest effects of $\mathrm{CH}_{2} \mathrm{~N}_{2}$ and $\mathrm{CaNH}_{4} \mathrm{NO}_{3}$ treatment on the sensory quality of sweet cherry have not been documented.

Dever etal.(1996) cited studies identifying important sensory qualities of sweet cherries and consumer preferences for sweet cherries at retail markets. These sensory qualities were divided into visual or taste quality parameters with the objective of forming sensory profiles of promising cultivars in sweet cherry breeding programs (Cliffet al., 1996; Dever et al., 1996). For 'Bing', an established sweet cherry cultivar, visual quality of non-stored fruit appeared largely unaffected by preharvest treatments of $\mathrm{CH}_{2} \mathrm{~N}_{2}, \mathrm{CaNH}_{4} \mathrm{NO}_{3}$, and $\mathrm{GA}_{3}$ (Clayton et al., 2003); however, the sensory taste quality of treated fruit may be affected. The objectives of this study were to determine if preharvest treatments of $\mathrm{CH}_{2} \mathrm{~N}_{2}, \mathrm{CaNH}_{4} \mathrm{NO}_{3}$, and $\mathrm{GA}_{3}$ impacted the postharvest sensory taste quality of 'Bing' sweet cherry fruit and whether any such impact was consistent for fruit of different levels of maturity.

\section{Materials and Methods}

In 1998, 1999, and 2000, 'Bing' sweet cherries were obtained from moderately cropping, mature trees of moderate vigor grown on Maheleb rootstocks in separate commercial orchards each year located on loam-textured soils in the Central Valley of California. Within each orchard the experiment was organized as a randomized complete block design comprised of three blocks and four treatments with one tree representing a treatment plot within each block. Treatments included $\mathrm{CH}_{2} \mathrm{~N}_{2}$ (Dormex, SKW Trostberg, Trostberg, Germany) at 7.8 $\mathrm{kg} \cdot \mathrm{ha}^{-1}$ a.i. in $935 \mathrm{~L}$ of water, $\mathrm{CaNH}_{4} \mathrm{NO}_{3}-9 \%$ $\mathrm{Ca}$ and $17 \% \mathrm{~N}$ w/w (CAN17; Unocal Corp., El Segundo, Calif.) at $468 \mathrm{~L} \cdot \mathrm{ha}^{-1}$ of solution in $1400 \mathrm{~L}$ of water applied with surfactant (Optima, Helena Chemical Co., Memphis, Tenn.) at $37 \mathrm{~L} \cdot \mathrm{ha}^{-1}, \mathrm{GA}_{3}$ (ProGibb 4\%, Valent USA Corp., Walnut Creek, Calif.) at $60 \mathrm{~g} \cdot \mathrm{ha}^{-1}$ a.i. in $1870 \mathrm{~L}$ of water, and untreated cherries representing the Control treatment. The $\mathrm{CH}_{2} \mathrm{~N}_{2}$ and $\mathrm{CaNH}_{4} \mathrm{NO}_{3}$ treatments were applied to the trees during the dormant period in midJanuary of all 3 years. $\mathrm{GA}_{3}$ was applied just before fruit straw color development in May of all 3 years.

Cherry harvest occurred during the commercial harvest period for fruit of each treatment, typically when most of the crop was at the red and mahogany stages of skin color development. This corresponded to 25,31, and 18 May for $\mathrm{CH}_{2} \mathrm{~N}_{2}$-treated cherries, 4 and 7 June and 21 May for $\mathrm{CaNH}_{4} \mathrm{NO}_{3}$-treated cherries, 8 June and 8 and 23 May for the control treatment, and 9 June and 9 and 29 May for GA -treated fruit for the years 1998, 1999, and 2000, respectively. At each harvest, proportionate samples of cherries were obtained from the inner and outer canopy of all sides of the trees. Defect-free fruit were segregated into four maturity categories based on skin color: salmon (1), red (3), mahogany (4), and 
Table 1. Sensory taste scores of 'Bing' cherries between preharvest treatments, years, and skin color categories.

\begin{tabular}{|c|c|c|c|c|}
\hline Parameter & Firmness $^{z}$ & Sweetness $^{z}$ & Tartness $^{\mathrm{z}}$ & Cherry flavor $^{2}$ \\
\hline \multicolumn{5}{|l|}{ Treatment ${ }^{y}$} \\
\hline $\mathrm{CH}_{2} \mathrm{~N}_{2}$ & $5.7 b^{x}$ & $4.1 \mathrm{~b}$ & 5.1 & $4.1 \mathrm{ab}$ \\
\hline $\mathrm{CaNH}_{4} \mathrm{NO}_{3}$ & $5.3 \mathrm{c}$ & $4.0 \mathrm{~b}$ & 5.1 & $3.9 \mathrm{~b}$ \\
\hline Control & $5.3 \mathrm{c}$ & $4.3 \mathrm{a}$ & 5.0 & $4.3 \mathrm{a}$ \\
\hline $\mathrm{GA}_{3}$ & $6.3 \mathrm{a}$ & $4.4 \mathrm{a}$ & 4.9 & $4.3 \mathrm{a}$ \\
\hline \multicolumn{5}{|l|}{ Year ${ }^{3}$} \\
\hline 1998 & $6.0 \mathrm{a}$ & $3.8 \mathrm{c}$ & 4.8 & $4.0 \mathrm{~b}$ \\
\hline 1999 & $5.0 \mathrm{~b}$ & $4.0 \mathrm{~b}$ & 5.1 & $3.9 \mathrm{~b}$ \\
\hline 2000 & $6.1 \mathrm{a}$ & $4.8 \mathrm{a}$ & 5.2 & $4.6 \mathrm{a}$ \\
\hline \multicolumn{5}{|l|}{ Color category } \\
\hline Salmon & $6.0 \mathrm{a}$ & $2.0 \mathrm{~d}$ & $6.5 \mathrm{a}$ & $2.2 \mathrm{~d}$ \\
\hline Red & $5.4 \mathrm{~b}$ & $3.2 \mathrm{c}$ & $5.5 \mathrm{~b}$ & $3.3 \mathrm{c}$ \\
\hline Mahogany & $5.4 \mathrm{~b}$ & $5.1 \mathrm{~b}$ & $4.3 \mathrm{c}$ & $5.0 \mathrm{~b}$ \\
\hline Dark mahogany & $5.8 \mathrm{a}$ & $6.4 \mathrm{a}$ & $3.8 \mathrm{~d}$ & $6.2 \mathrm{a}$ \\
\hline \multicolumn{5}{|l|}{ Source } \\
\hline Treatment (T) & *** & $* * *$ & NS & $*$ \\
\hline Year $(\mathrm{Y})$ & *** & $* * *$ & NS & *** \\
\hline Color category (C) & *** & $* * *$ & $* * *$ & $* * *$ \\
\hline $\mathrm{T} \times \mathrm{Y}$ & $* *$ & $* * *$ & $* * *$ & ** \\
\hline $\mathrm{T} \times \mathrm{C}$ & NS & NS & NS & NS \\
\hline $\mathrm{Y} \times \mathrm{C}$ & $* * *$ & $* * *$ & NS & $* * *$ \\
\hline $\mathrm{T} \times \mathrm{Y} \times \mathrm{C}$ & NS & NS & NS & NS \\
\hline
\end{tabular}

${ }^{2}$ Higher sensory scores reflect increased sensory firmness, sweetness, tartness, and cherry flavor intensity, on a 1 to 10 hedonic scale.

${ }^{y} \mathrm{CH}_{2} \mathrm{~N}_{2}=$ hydrogen cyanamide, $\mathrm{CaNH}_{4} \mathrm{NO}_{3}=$ calcium ammonium nitrate, Control = untreated, $\mathrm{GA}_{3}=$ gibberellic acid.

${ }^{\times}$Mean separation within columns and factors by LSD, $P \leq 0.05$.

NS,***,****Nonsignificant or significant at $P \leq 0.05,0.01$, or 0.001 , respectively.

dark mahogany (6), the numbers corresponding to color category chips (Centre Technique Interprofessional des Fruits et Legumes, Paris, France), and held overnight at $0^{\circ} \mathrm{C}$ in unsealed plastic bags.

Each year a sensory panel of 20 persons (university employees and students) underwent training to enhance their sensory perceptiveness of cherry fruit, to familiarize them with the selected taste quality traits, and to specify sensory analysis protocols. Basker (1977) reported that 8 to 20 sensory panelists could be used for a preliminary estimate of consumer response. Sensory panelists had no knowledge of which preharvest treatment they were evaluating, nor were they involved in the study beyond the sensory evaluation.

Test one. The sensory flavor and texture traits evaluated were those also used by Cliffet al. (1996) and Dever et al. (1996), cherry flesh firmness, sweetness, tartness, and cherry flavor. For each of the treatments, sensory evaluations were conducted the day after harvest with fruit warmed from 0 to $20^{\circ} \mathrm{C}$. Tasting occurred in individual booths illuminated by a dim green light whereby the fruit were observed through green lenses to obscure skin color (Crisosto 2002). Panelists were presented with three groups (replications or blocks) of four numerically coded cups with each of the four cups containing a cherry randomly obtained from one of the four skin-color categories within a block. Each cherry was assessed for sensory firmness (based on initial fruit mastication), sweetness, tartness, and cherry flavor, and the assessment recorded with a vertical line drawn on a $10-\mathrm{cm}$ horizontal line anchored by the labels "less" and "more" for each trait. Numerical values were assigned to each sensory assessment by measuring the distance from the vertical assessment line to the anchor labeled 'less' at the origin of the horizontal line.

Test two. Additional Control and $\mathrm{GA}_{3}$ fruit were harvested on 29 May 2000. Unblemished 'Bing' cherries were sorted into the four skin-color categories as previously described and stored at $0{ }^{\circ} \mathrm{C}$. The following day, fruit were warmed to $20{ }^{\circ} \mathrm{C}$ and their firmness measured nondestructively by force/deformation $\left(\mathrm{g} \cdot \mathrm{mm}^{-1}\right)($ FirmTech1, BioWorks Incorp., Stillwater, Okla.). For each of the treatments, cherries were ranked by instrumental firmness and divided by quartiles. One cherry within each firmness quartile of each treatment was randomly assigned to each taste panelist. The order that fruit of each firmness category and treatment was presented to the panelists was also randomized. Fruit were supplied to the panelists in individual cups under the illuminative conditions previously described whereby each sample was assessed for firmness based on initial mastication of the fruit. Firmness assessment was recorded on a $10-\mathrm{cm}$ line and quantified as previously described.

Analysis. Results were analyzed by analysis of variance whereby the main sources of variation for test one were treatment, year, and fruit skin color category, and for test two was treatment. Panelist performance was not an objective and was not analyzed as a source of variation for either test. Interactions between treatment, year, and color category for test one were analyzed for significance.

\section{Results and Discussion}

Fruit firmness, perceived by the taste panel during initial mastication of the fruit, was higher in $\mathrm{GA}_{3}$-treated fruit as compared with $\mathrm{CH}_{2} \mathrm{~N}_{2}, \mathrm{CaNH}_{4} \mathrm{NO}_{3}$, and Control fruit (Table 1). While previous studies utilizing instruments to measure firmness have con- cluded that $\mathrm{GA}_{3}$-treated sweet cherries were firmer than untreated cherries (Proebsting et al., 1973; Facteau and Rowe, 1979; Facteau, 1982; Facteau et al., 1985; Looney and Lidster, 1980), our data indicate that such differences are within human sensory perception. Overall, $\mathrm{CH}_{2} \mathrm{~N}_{2}$-treated cherries were sensed as firmer than $\mathrm{CaNH}_{4} \mathrm{NO}_{3}$ and Control cherries in spite of there being no differences between the three treatments in 1999 (Fig. 1A), a year of relatively softer fruit. There were no differences in sensory firmness between $\mathrm{CaNH}_{4} \mathrm{NO}_{3}$ and Control cherries. With respect to maturity, skin color has been considered a reliable maturity criterion for 'Bing' (Clayton et al., 2003; Facteau et al., 1983; Proebsting and Mills, 1981). However, sensory firmness was not consistently related to fruit skin color across years (Fig. 2A). Immature, salmon-colored cherries were significantly firmer than red, mahogany, and dark mahogany cherries in 1998. Surprisingly, dark mahogany-colored cherries were rated firmer than red and mahogany colored cherries in 1998 and 1999, yet measurements of 'Bing' cherries using a number of instruments have previously revealed relatively strong correlations between skin color and fruit firmness with lighter colored fruit showing higher firmness (Mitcham et al., 1998). The taste panelists did not detect differences in firmness between the four levels of fruit maturity in 2000 (Fig. 2A).

The supplemental firmness evaluation conducted in 2000 (test 2) confirmed that $\mathrm{GA}_{3}$ treated cherries had higher sensory firmness than untreated cherries (Table 2). In contrast to previous studies (Facteau and Rowe, 1979; Facteau, 1982; Facteau et al., 1985; Looney and Lidster, 1980; Proebsting et al., 1973), instrumental firmness of the exact same $\mathrm{GA}_{3}$ treated cherries was not significantly greater than untreated cherries for reasons that were unclear. Correlation coefficients between sensory and instrumental firmness were relatively strongly $(P<0.001)$ at 0.60 and 0.61 for untreated and $\mathrm{GA}_{3}$ cherries, respectively, with both correlations exhibiting strong parallelism (data not shown). These data further indicates that sensory firmness of $\mathrm{GA}_{3}$-treated fruit was consistently greater than untreated fruit across the full range of fruit maturities included in this study.

On average, cherry sweetness for each treatment was perceived as relatively low in 1998 and 1999 with ratings of 3.8 and 4.0, respectively, out of a possible 10 (Table 1). The weather before cherry harvest was coolest in 1998 and warmest in 2000, and may have influenced seasonal variability in sugar content. However, the apparent, extreme lack of sweetness detected in salmon and red colored cherries disproportionately reduced the mean sweetness scores. Cherries treated with $\mathrm{CH}_{2} \mathrm{~N}_{2}$ and $\mathrm{CaNH}_{4} \mathrm{NO}_{3}$ were perceived as being significantly less sweet than Control and $\mathrm{GA}_{3}$ cherries. In contrast, the taste panelists did not detect differences in cherry tartness between treatments combined across years or between years themselves (Table 1). However, the interaction of treatment and year was significant for sensory sweetness and tartness and revealed that $\mathrm{GA}_{3}$ and Control fruit were considerably 

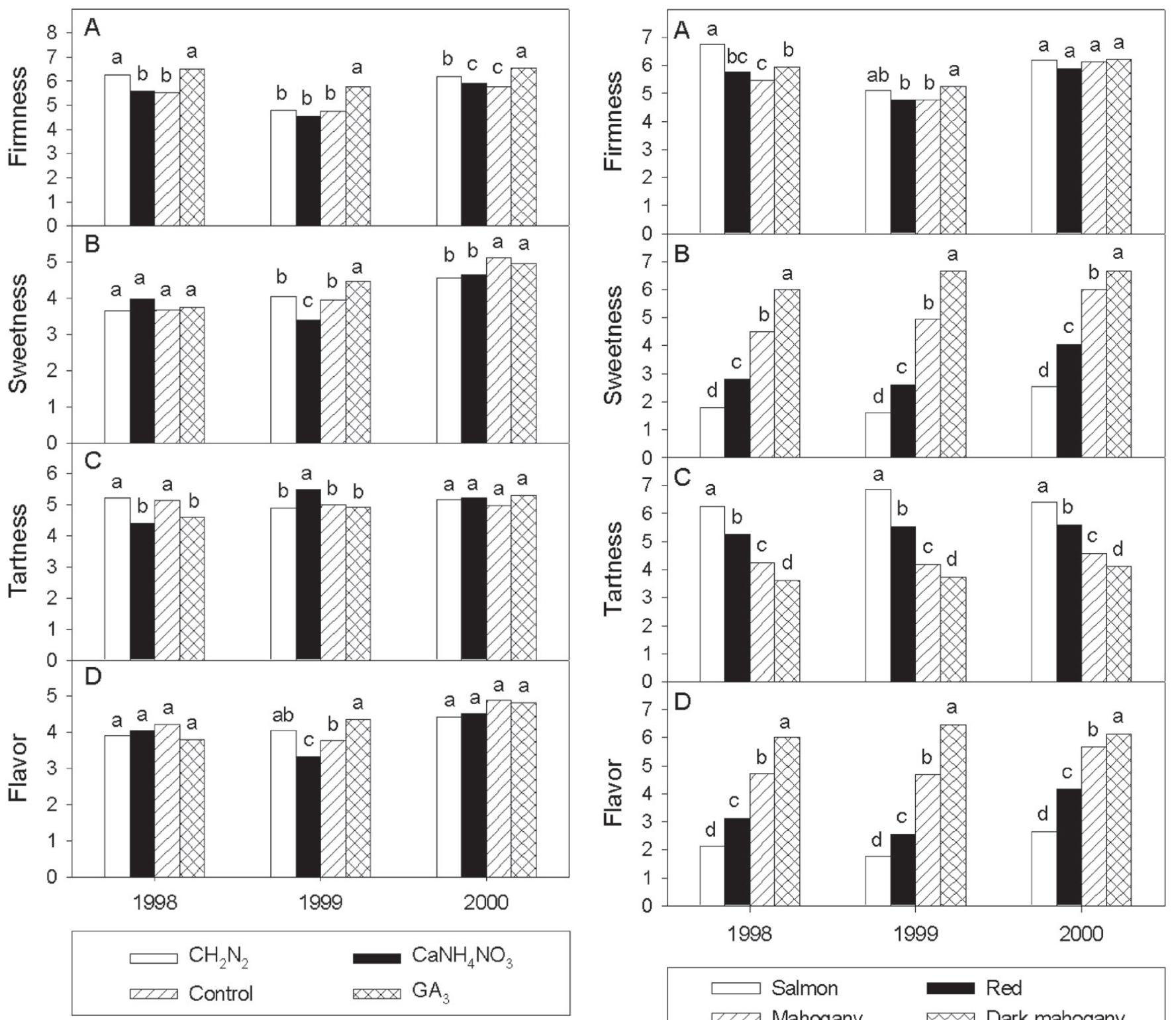

Fig. 1. Sensory firmness (A), sweetness (B), tartness (C), and cherry flavor (D) of 'Bing' cherries averaged across panelists and skin color categories following preharvest treatment with hydrogen cyanamide $\left(\mathrm{CH}_{2} \mathrm{~N}_{2}\right)$, calcium ammonium nitrate $\left(\mathrm{CaNH}_{4} \mathrm{NO}_{3}\right)$, or gibberellic acid $\left(\mathrm{GA}_{3}\right)$. Higher sensory scores reflect increased sensory firmness, sweetness, tartness, and cherry flavor intensity, as measured on a 1 to 10 hedonic scale. Mean separation within quality attributes and years by $\operatorname{LSD}(P \leq 0.05)$.

sweeter in 2000, but did not differ with $\mathrm{CH}_{2} \mathrm{~N}_{2}$ and $\mathrm{CaNH}_{4} \mathrm{NO}_{3}$ fruit in 1998, while $\mathrm{GA}_{3}$ fruit were sweeter than all other treatments in 1999 (Fig. 1B). $\mathrm{CaNH}_{4} \mathrm{NO}_{3}$ fruit was the most tart in 1999 , yet $\mathrm{CH}_{2} \mathrm{~N}_{2}$ and Control fruit were most tart in 1998, and differences between treatments in 2000 were negligible (Fig. 1C). The inconsistency between treatments for sensory sweetness and tartness across the years is not well understood. Cliff et al. (1996) suggested various panelist-related reasons for a wide variation in certain sensory perceived texture/ flavor attributes including a lack of sensitivity to the attributes, inconsistency in preference, and a broad range in

flavor/texture liking. Furthermore, there have been conflicting reports as to the effects of $\mathrm{GA}_{3}$ on objective measurements of soluble solids content and titratable acidity of sweet cherry (Facteau, 1982; Looney and Lidster, 1980; Proebsting et al., 1973), suggesting the strong influence of factors other than $\mathrm{GA}_{3}$ interacting with these attributes. Soluble solids content in sour cherry has also been shown to vary between years (Iezzoni, 1986). There were discrete differences between the four color categories for sweetness and tartness, as darker cherries of more advanced maturity were sweeter and less tart than lighter colored cherries (Table $1)$. This effect was relatively consistent across years for sweetness (Fig. 2B) and tartness (Fig. 2C), although dark-mahogany fruit were not as proportionally sweet in 2000 as compared with 1998 and 1999.

Cherry flavor reflected similar scores to sensory sweetness when means were calculated for treatments, years, or skin color categories (Table 1). As with sensory sweetness, cherry flavor was rated higher for $\mathrm{GA}_{3}$ and Control
Fig. 2. Sensory firmness (A), sweetness (B), tartness (C), and cherry flavor (D) of 'Bing' cherries averaged across panelists and treatments following segregation of fruit into skin color categories of salmon, red, mahogany, and dark mahogany fruit. Higher sensory scores reflect increased sensory firmness, sweetness, tartness, and flavor intensity, as measured on a 1 to 10 hedonic scale. Mean separation within color categories and years by $\operatorname{LSD}(P \leq 0.05)$.

fruit, with $\mathrm{CaNH}_{4} \mathrm{NO}_{3}$ fruit rated as having the lowest flavor when treatments were averaged across years. However, between years there were few consistent differences between treatments (Fig. 1D). Cliff et al. (1996) also found a close association between cherry flavor and sensory sweetness in 'Bing' and other cherry cultivars, while Dever et al. (1996) found a good association between cherry flavor and soluble solids content. Surprisingly, both studies showed a relatively weak association between soluble solids content and sensory sweetness. Sensory panelists found that progressively darker colored fruit had significantly 
Table 2. Sensory and instrumental firmness of $\mathrm{GA}_{3}{ }^{2}$ and non-GA - -treated 'Bing' cherries.

\begin{tabular}{lcc}
\hline Parameter & $\begin{array}{c}\text { Sensory } \\
\text { firmness }\end{array}$ & $\begin{array}{c}\text { Instrumental }^{\mathrm{x}} \\
\text { firmness } \\
\left(\mathrm{N} \cdot \mathrm{mm}^{-1}\right)\end{array}$ \\
\hline $\begin{array}{c}\text { Treatment } \\
\mathrm{GA}_{3}{ }^{\mathrm{x}}\end{array}$ & $6.7 \mathrm{a}^{\mathrm{w}}$ & 1.91 \\
$\quad \begin{array}{l}\text { Non-GA } \\
\text { Source of variation }\end{array}$ & $5.3 \mathrm{~b}$ & 1.85 \\
$\quad$ Treatment & $* * *$ & $\mathrm{NS}$ \\
\hline
\end{tabular}

${ }^{\mathrm{z}} \mathrm{GA}_{3}=$ gibberellic acid.

${ }^{\mathrm{y}}$ Higher sensory scores reflect increased sensory firmness on a 1 to 10 hedonic scale.

${ }^{x}$ FirmTech1, BioWorks Incorp., Stillwater, Okla.

wMean separation within columns by LSD $(P \leq$ $0.05)$.

NS, ${ }^{* * *}$ Nonsignificant or significant at $P \leq 0.001$, respectively.

more cherry flavor than lighter colored fruit; however, the dark mahogany fruit in 2000 were not as proportionately flavorful as they were in previous years (Fig. 2D), probably resulting in the interaction of treatment and year (Table 1).

The treatments appeared to have consistently impacted sensory firmness more so than sweetness, tartness, or cherry flavor. GA and $\mathrm{CH}_{2} \mathrm{~N}_{2}$ fruit were consistently determined by panelists to be firmer than untreated and $\mathrm{CaNH}_{4} \mathrm{NO}_{3}$ fruit, although $\mathrm{CH}_{2} \mathrm{~N}_{2}$ fruit were significantly firmer in only two of the three years. Meanwhile, mature, dark mahogany cherries were periodically determined to have higher sensory firmness than lighter red or mahogany cherries, contrasting with reports to the contrary when cherry firmness was measured objectively (Clayton et al., 2003; Mitcham et al., 1998). In spite of numerous studies reporting improved firmness in $\mathrm{GA}_{3}$ treated cherries, instrumental firmness of $\mathrm{GA}_{3}$ fruit in this study did not increase significantly at the $5 \%$ probability level despite higher sensory firmness for $\mathrm{GA}_{3}$ fruit. Nonetheless, instrumental and sensory firmness correlated reasonably well and with similar strength for both $\mathrm{GA}_{3}$ and untreated cherries, concurring with Kappel et al. (1996) who reported good correlations between sensory and objective firmness of untreated sweet cherries. Despite considerable variability between treatments for sweetness and cherry flavor across years, $\mathrm{GA}_{3}$ cherries either maintained or had marginally higher ratings for sweetness and cherry flavor compared to untreated cherries while
$\mathrm{CH}_{2} \mathrm{~N}_{2}$ cherries typically maintained or occasionally rated lower compared to untreated cherries. $\mathrm{CaNH}_{4} \mathrm{NO}_{3}$ cherries typically had slightly less or occasionally similar ratings for sweetness and cherry flavor compared to untreated cherries.

The benefits of firmer cherries include reduced susceptibility to decay organisms and mechanical injury, enhanced storage potential, and increased appeal to consumers (Brown and Bourne, 1988). Sweetness and cherry flavor intensity are also important attributes for overall flavor preference, and increases in both attributes resulted in increased consumer preference (Cliff et al., 1996). In comparison with untreated cherries, $\mathrm{GA}_{3}$-treated 'Bing' cherries can therefore be considered to have improved sensory taste quality, evident by improved firmness whilst, in the least, maintaining sweetness, cherry flavor, and tartness. $\mathrm{CH}_{2} \mathrm{~N}_{2}$-treated cherries had somewhat greater perceived firmness, but otherwise were similar to untreated fruit in terms of sensory quality. The quality of $\mathrm{CaNH}_{4} \mathrm{NO}_{3}$-treated cherries often suffered compared to untreated cherries as evident from reduced sweetness and cherry flavor intensity in some years. These findings suggest that benefits may be realized at retail markets supplied with $\mathrm{GA}_{3}$-treated 'Bing' cherries due to increased consumer satisfaction. $\mathrm{CH}_{2} \mathrm{~N}_{2}$ may be useful to cherry producers for manipulating tree dormancy and fruit maturation while not impacting negatively on sensory quality of the fruit. $\mathrm{CaNH}_{4} \mathrm{NO}_{3}$ treatment of 'Bing' cherries was found, more often than not, to negatively impact sensory taste quality.

\section{Literature Cited}

Basker, D. 1977. The number of assessors required for taste panels. Chemical Senses Flavor 2:493-496.

Brown, S.K. and M.C. Bourne. 1988. Assessment of components of fruit firmness in selected sweet cherry genotypes. HortScience 23:902-904.

Ceponis, M.J. and J.E. Butterfield. 1981. Cull losses in western sweet cherries at retail and consumer levels in metropolitan New York. HortScience 16(3):324-326.

Clayton, M., W.V. Biasi, I.T. Agar, S.M. Southwick, and E.J. Mitcham. 2003. Postharvest quality of 'Bing' cherries following preharvest treatment with hydrogen cyanamide, calcium ammonium nitrate, or gibberellic acid. HortScience 38(3):407-411.

Cliff, M.A., M.C. Dever, J.W. Hall, and B. Girard.
1996. Development and evaluation of multiple regression models for prediction of sweet cherry liking. Food Res. Intl. 28(6):583-589.

Crisosto, C.H., G.M. Crisosto, and M.A. Ritenour. 2002. Testing the reliability of skin color as an indicator of quality for early season 'Brooks' (Prunus avium L.) cherry. Postharvest Biol. Technol. 24(2):147-154.

Dever, M.C., R.A. MacDonald, M.A.Cliff, and W.D. Lane. 1996. Sensory evaluation of sweet cherry. HortScience 31(1):150-153.

Facteau, T.J. 1982. Levels of pectic substances and calcium in gibberellic acid-treated sweet cherry fruit. J. Amer. Soc. Hort. Sci. 107(1):148-151.

Facteau, T.J., N.E. Chestnut, and K.E. Rowe. 1983. Relationship between fruit weight, firmness, and leaf/fruit ratio in Lambert and Bing sweet cherries. Can. J. Plant Sci. 63:763-765.

Facteau, T.J., K.E. Rowe, and N.E. Chestnut. 1985 Firmness of sweet cherry fruit following multiple applications of gibberellic acid. J. Amer. Soc. Hort. Sci. 110(6):775-777.

Facteau, T.J. and K.E. Rowe. 1979. Factors associated with surface pitting of sweet cherry. J. Amer. Soc. Hort. Sci. 104(5):706-710.

Iezzoni, A.F. 1986. Variance components and sampling procedures for fruit size and quality in sour cherry. HortScience 21(4):1040-1042.

Kappel, F, B. Fisher-Fleming, and E. Hogue. 1996. Fruit characteristics and sensory attributes of an ideal sweet cherry. HortScience 31(3):443-446.

Looney, N.E. and P.D. Lidster. 1980. Some growth regulator effects on fruit quality, mesocarp composition, and susceptibility to postharvest surface marking of sweet cherries. J. Amer. Soc. Hort. Sci. 105(1):130-134.

Mitcham, E.J., M. Clayton, and W.V. Biasi. 1998. Comparison of devices for measuring cherry fruit firmness. HortScience 33(4):723-727.

Proebsting, E.L., G.H. Carter, and H.H. Mills. 1973. Quality improvement in canned 'Rainier' cherries $(P$. avium L.) with gibberellic acid. J. Amer. Soc. Hort. Sci. 98(4):334-336.

Proebsting, E.L. and H.H. Mills. 1981. Effects of season and crop load on maturity characteristics of 'Bing' cherry. J. Amer. Soc. Hort. Sci. 106(2):144-146.

Weis, K.G., S.M. Southwick, J.T. Yeager, M.E Rupert, and W.W. Coates. 1998. Control of dormancy and budbreak in sweet cherry (Prunus avium L.) cv 'Bing' with surfactant + calcium ammonium nitrate and hydrogen cyanamide. HortScience 33(3):514.

Weis, K.G., S.M. Southwick, J.T. Yeager, M.E. Rupert, R.E. Moran, J.A. Grant, and W.W. Coates. 1999. Overcoming dormancy, advancing budbreak, and advancing fruit maturity in 'Bing' sweet cherry (Prunus avium L.): Surfactants/ dormant oils + calcium ammonium nitrate or hydrogen cyanamide. HortScience 34(3):525. 